\title{
Repercussions of COVID-19 in Brazilian Dentists' Personal and Professional Routines: An Online Survey
}

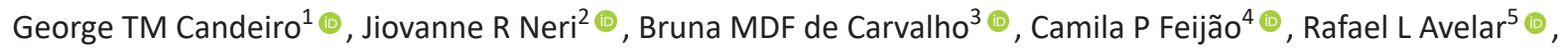 \\ José VM Lemos ${ }^{6}$, Anya PGF Vieira-Meyer ${ }^{7}$ (이
}

\begin{abstract}
Aim and objective: This study evaluated the repercussions of coronavirus disease-2019 (COVID-19) in Brazilian dentists'personal and professional routines.

Materials and methods: Brazilian dentists were invited to participate in an online survey with questions pertaining to COVID-19 and its repercussions in dental practice. Sample calculation was performed using the Survey Monkey software (www.surveymonkey.com). The minimum sample required to obtain a $95 \%$ confidence level $(\mathrm{Cl})$ and $1 \%$ margin of error was 4,214 . The eligibility criteria were dental professionals, of any gender and age, who were working in dentistry in a public, private, or university environment, regardless of the time of experience in the profession, and agreed to participate in the study. The survey was structured such that all the Brazilian regions were touched upon, thereby aiming at covering and collecting the representative data of the region. Responses were analyzed using chi-square tests, $t$-tests, and one-way analysis of variance, with statistical significance at $p<0.05$

Results: A total of 15,813 dentists responded to the survey, representing all Brazilian regions. Complete social isolation was practiced by $96.21 \%$ of the respondents, and approximately $25 \%$ knew someone who had contracted COVID-19. Public health specialists were the most likely to provide emergency treatment $(71.90 \%, p<0.001)$. In the Northeast region, $79.80 \%$ of respondents agreed that conventional personal protective equipment (PPE) was insufficient to prevent COVID-19 transmission, and $79.10 \%$ considered their biosecurity measures insufficient ( $p<0.001)$. In the North region, most dentists continued to perform elective dental procedures $(p<0.001)$.

Conclusion: It is possible to conclude that Brazilian dentists demonstrated high knowledge of COVID-19's main symptoms and the risks of transmission through dental procedures. Most respondents practiced social isolation, although some did continue to provide emergency dental care.

Clinical significance: To improve infection control in dental care settings against COVID-19, it is necessary to educate and raise awareness among professionals.

Keywords: Coronavirus infections, Dentists, Pandemics.

The Journal of Contemporary Dental Practice (2021): 10.5005/jp-journals-10024-3096
\end{abstract}

\section{INTRODUCTION}

Coronavirus disease 2019-(COVID-19), an illness caused by a novel coronavirus, became a pandemic due to its rapid spread and has been compared to the Spanish flu pandemic of 1918. The first cases of COVID-19 emerged in Wuhan, China, in December 2019. The virus was first identified on January 7, 2020, through throat swab samples analyzed by the Chinese Center for Disease Control and Prevention. ${ }^{1,2}$ On January 30, following the global outbreak of COVID-19, the World Health Organization (WHO) declared a public health emergency. On March 11, the WHO identified the disease as a pandemic. ${ }^{3}$

The COVID-19 virus is transmitted through close contact with infected individuals, who may be symptomatic or asymptomatic. The main route of transmission is respiratory droplet (dry cough, sneeze, and stray) or saliva contact in the oral, nasal, or eye mucosa. The virus's incubation period is estimated to be between 2 days and 10 days, and no more than 14 days. ${ }^{1,3}$ The most common symptoms of COVID-19 are headache, high fever, diarrhea, muscle aches, dry cough, sore throat, and shortness of breath; in more severe cases, patients experience dyspnea, respiratory distress syndrome, septic shock, metabolic acidosis, and coagulation dysfunction. Most patients manifest moderate symptoms and have a good prognosis. Older patients with comorbidities are at higher risk for severe disease and death. ${ }^{1,2}$

Due to its rapid transmissibility, critical public health measures are required to delay the spread of COVID-19. Targeted vaccines
1,3-6 University Center Christus (Unichristus), Fortaleza, Ceará, Brazil

${ }^{2}$ University Center Christus (Unichristus), Fortaleza, Ceará, Brazil; School of Dentistry, University of Fortaleza (Unifor), Fortaleza, Ceará, Brazil

${ }^{7}$ University Center Christus (Unichristus), Fortaleza, Ceará, Brazil; Oswaldo Cruz Foundation (FIOCRUZ- Ceará), Fortaleza, Ceará, Brazil

Corresponding Author: Jiovanne R Neri, University Center Christus (Unichristus), Fortaleza, Ceará, Brazil; School of Dentistry, University of Fortaleza (Unifor), Fortaleza, Ceará, Brazil E-mail: jiovanne@hotmail.com How to cite this article: Candeiro GTM, Neri JR, Carvalho BMDF, et al. Repercussions of COVID-19 in Brazilian Dentists' Personal and Professional Routines: An Online Survey. J Contemp Dent Pract 2021;22(5):491-500.

Source of support: Nil

Conflict of interest: None

and drugs remain in development; thus, the WHO's main recommendations are social isolation and quarantine of infected individuals to avoid the potential collapse of health systems in multiple countries. ${ }^{4}$

In the world, on April 23, 2021, there are a total of 144,358,956 confirmed cases of COVID-19, including 3,066,113 deaths associated with the disease. As of April 23, 2021, the highest rates of confirmed cases and deaths were observed in the United States of America 
(31,530,214 cases and 564,091 deaths), India $(16,263,695$ cases and 186,920 deaths), France (5,352,495 cases and 101,513 deaths), Russian Federation (4,744,961 cases and 107,501 deaths) and The United Kingdom (4,398,435 cases and 127,345 deaths). ${ }^{5}$ In Brazil, according to the Ministry of Health, there are $14,167,973$ confirmed cases and 383,502 deaths in Brazil, April on 23, 2021. ${ }^{6}$ Brazil is the world's fifth-largest country $\left(8,515,767 \mathrm{~km}^{2}\right)$, with continental dimensions and five geographically divided regions: the North, Northeast, South, Southeast, and Midwest. The Brazilian population is estimated to be around $210,000,000 .^{7}$ The Federal Council of Dentistry reports almost 300,000 dentists in Brazil, with the greatest concentration in the Southeast and the least in the North. ${ }^{8}$

Given the widespread transmission of COVID-19, dental professionals are at high risk for nosocomial infection and can become potential carriers of the disease. ${ }^{9}$ Dental procedures expose professionals to work closely with patient's oropharyngeal region, handling instruments contaminated with saliva and producing many droplets and aerosols. ${ }^{9,10}$ Thus, dental associations and other entities recommend limiting dental care to emergency treatment, postponing elective dental treatments, and intensifying biosecurity measures. ${ }^{9,10}$ In light of these circumstances, this study evaluated the repercussions of COVID-19 in Brazilian dentists' personal and professional routines.

\section{Materials and Methods}

This is a cross-sectional study that was developed in the state of Ceará (Brazil) and conducted from March 28 to 31, 2020. Sample calculation was performed using the SurveyMonkey software (www.surveymonkey.com). The minimum sample required to obtain a 95\% confidence level $(\mathrm{Cl})$ and $1 \%$ margin of error was 4,214. The eligibility criteria were dental professionals, of any gender and age, who were working in dentistry in a public, private, or university environment, regardless of the time of experience in profession, and agreed to participate in the study.

After approval by Ethics Committee (Protocol number: 30535020.5.0000.5049), a list of dentists was acquired with the professional councils of each Brazilian state. A link to an online survey on Google Forms (Google LLC, Mountain View, CA, USA) (Table 1) was sent to approximately 70,000 dental professionals via the WhatsApp, Instagram, and Facebook social networks. All social networks mentioned were used to give dentists access to research.

Before the questionnaire started, all participants were informed about the purpose and importance of the survey. Additionally, the participants were asked about the consent to participate in the study, and all individual information was guarded by the researcher's confidentiality.

The online questionnaire consisted of 15 items and had two sections. Section one included five closed questions (Table 1) regarding personal information (age, clinical practice type and location, duration since graduation, and field of specialty). To encourage unbiased responses, the survey did not ask participants to provide any personally identifying information.

Section two consisted of 10 closed questions (Table 1) pertaining to COVID-19, its repercussions in dental practice, dentists' knowledge of COVID-19 symptoms and biosecurity measures during dental care, and whether they performed elective and/or emergency procedures during the social isolation period determined by the relevant local governments.

Descriptive and bivariate analyses were performed using STATA SE 14.2. Means and standard deviations were calculated
Table 1: Baseline questionnaire and answers

\begin{tabular}{|c|c|c|}
\hline & $n$ & Percentage \\
\hline \multicolumn{3}{|l|}{ Personal questions } \\
\hline \multicolumn{3}{|l|}{ Country region } \\
\hline North & 528 & 3.34 \\
\hline Northeast & 2,779 & 17.57 \\
\hline Southeast & 9,573 & 60.54 \\
\hline South & 1,530 & 9.68 \\
\hline Midwest & 1,403 & 8.87 \\
\hline Total & 15,813 & 100.00 \\
\hline \multicolumn{3}{|l|}{ Age } \\
\hline $21-30$ years old & 2,727 & 17.25 \\
\hline 31-40 year old & 4,267 & 26.98 \\
\hline $41-50$ years old & 4,819 & 30.47 \\
\hline $51-60$ years old & 3,086 & 19.52 \\
\hline $61-70$ years old & 853 & 5.39 \\
\hline$>70$ years old & 61 & 0.39 \\
\hline Total & 15,813 & 100.00 \\
\hline \multicolumn{3}{|l|}{ Gender } \\
\hline Male & 4,934 & 31.21 \\
\hline Female & 10,873 & 68.77 \\
\hline Male transgender & 3 & 0.02 \\
\hline Female transgender & 3 & 0.02 \\
\hline Total & 15,813 & 100.00 \\
\hline \multicolumn{3}{|l|}{ Time of experience } \\
\hline $0-5$ years & 2,697 & 17.06 \\
\hline $6-10$ years & 1,807 & 11.43 \\
\hline $11-15$ years & 2,131 & 13.24 \\
\hline $16-20$ years & 2,410 & 15.24 \\
\hline $21-30$ years & 3,976 & 25.14 \\
\hline$>30$ years & 2,792 & 17.66 \\
\hline Total & 15,813 & 100.00 \\
\hline \multicolumn{3}{|l|}{ Field of specialty } \\
\hline General dentistry & 4,408 & 27.88 \\
\hline Oral and maxillofacial surgery & 396 & 2.5 \\
\hline Restorative dentistry & 504 & 3.19 \\
\hline Orofacial pain/TMD & 206 & 1.3 \\
\hline Endodontics & 2,054 & 12.99 \\
\hline Stomatology & 83 & 0.52 \\
\hline Implant dentistry & 1,911 & 12.08 \\
\hline Labor dentistry & 50 & 0.32 \\
\hline Legal dentistry & 52 & 0.33 \\
\hline Special needs patients & 144 & 0.91 \\
\hline Periodontology & 777 & 4.91 \\
\hline Dental prosthesis & 1,078 & 6.82 \\
\hline Public health & 548 & 3.47 \\
\hline Others & 3,602 & 22.78 \\
\hline Total & 15,813 & 100.00 \\
\hline \multicolumn{3}{|l|}{ Specific questions } \\
\hline \multicolumn{3}{|c|}{$\begin{array}{l}\text { Indicate the main symptoms of COV- } \\
\text { ID-19. (You can select }>1 \text { ) }\end{array}$} \\
\hline Headache & 7,296 & 46.14 \\
\hline High fever & 12,621 & 79.81 \\
\hline
\end{tabular}


Contd...

\begin{tabular}{lcc}
\hline & $n$ & Percentage \\
\hline Low fever & 3,739 & 23.65 \\
Diarrhea & 4,661 & 29.48 \\
Muscle pain & 5,147 & 32.55 \\
Dry cough & 14,273 & 90.26 \\
Running nose & 5,777 & 36.53 \\
Sore throat & 9,405 & 59.48 \\
Sneeze & 4,039 & 25.54 \\
Shortness of breath & 14,444 & 91.34 \\
Vomiting & 1,027 & 6.49 \\
Where do you provide dental treatment? & & \\
(You can select >1)* & & \\
Private practice (own office) & 11,946 & 75.55 \\
Private practice (franchised/popular clinic) & 3,029 & 19.16 \\
Private practice (private hospital) & 335 & 2.12 \\
Public health (primary/secondary health care) & 3,914 & 24.75 \\
Public health (tertiary health care/public & & \\
hospital) & 361 & 2.28 \\
Private university/faculty & 738 & 4.67 \\
Public university/faculty & 295 & 1.87 \\
What procedures & &
\end{tabular}

What procedures do you consider safe to perform during the COVID-19 pandemic? (You can select $>1$ )*

None

$9,107 \quad 57.59$

Restorative and esthetic procedures

Surgical procedures

Endodontic treatment

Urgent/emergency treatments

All procedures

Can COVID-19 be transmitted through dental treatment?

Yes

No

I still have doubts

Do you think conventional PPE (gloves, hat, apron, mask, and goggles) is sufficient to prevent COVID-19 transmission?

Yes

No

Maybe

Do you consider the biosafety measures implemented in your work sufficient to prevent COVID-19 transmission?

Yes

No

I don't know

Are you performing elective dental procedures at your workplace during the pandemic period?

Yes

No

1,430

9.07

14,336

90.93

Are you performing emergency dental procedures at your workplace during the pandemic period?
Contd...

\begin{tabular}{lcc}
\hline & $n$ & Percentage \\
\hline Yes & 8,545 & 54.04 \\
No & 7,268 & 45.96 \\
$\begin{array}{l}\text { Are you and your family members } \\
\text { quarantined or practicing social isolation? }\end{array}$ & \\
Yes & 9,997 & 63.22 \\
No & 600 & 3.79 \\
$\begin{array}{l}\text { Yes, but 1 or more family members are still } \\
\text { working }\end{array}$ & 5,216 & 32.99 \\
$\begin{array}{l}\text { Do you know anyone who has been or is sick } \\
\text { with COVID-19? }\end{array}$ & \\
$\begin{array}{l}\text { Yes } \\
\text { No }\end{array}$ & \\
\hline
\end{tabular}

*The number of respondents was less

for continuous variables and frequencies and percentages for categorical variables. To evaluate dentists' knowledge of the main symptoms of COVID-19, correct answers were considered to be a headache, high fever, diarrhea, muscle aches, dry cough, sore throat, and shortness of breath; the number of these main symptoms correctly identified by each respondent was calculated. Bivariate analysis was conducted using chi-square tests, $t$-tests, and one-way analysis of variance (ANOVA). Statistical significance was set at $p<0.05$.

\section{RESULTS}

Among the 70,000 dentists invited to participate in the study, a total of 15,813 responded to the questionnaire $[10,873(68.77 \%)$ women, 4,934 (31.21\%) men, 3 (0.02\%) transgender women, and 3 $(0.02 \%)$ transgender men]. The sample represented dentists from all 5 Brazilian regions: North (3.3\%), Northeast (17.6\%), South (9.7\%), Southeast $(60.5 \%)$, and Midwest $(8.9 \%)$, according to the prior sample calculation (Table 1). Respondents' ages, time of experience, and field are described in Table 1. The majority of respondents (75.55\%) worked in private clinical practice, and $24.75 \%$ worked in public primary or secondary healthcare. Only $4.40 \%$ worked in hospital settings, and $6.54 \%$ in dental faculties or universities (Table 1). Participants working in more than one place could check more than one option. In this item, the questionnaire allowed more than one answer.

Almost all respondents (98.07\%) agreed that COVID-19 could be transmitted through dental procedures, and $73.93 \%$ of participants agreed that conventional personal protective equipment (PPE) was insufficient to prevent COVID-19 transmission. A total of $68.41 \%$ considered their workplace's biosecurity measures insufficient to prevent COVID-19 transmission, and $90.93 \%$ reported suspending elective dental procedures. Almost half of the participants $(54.04 \%)$ reported that their workplace limited care to emergency procedures only. Only $8.46 \%$ of respondents considered all dental procedures safe to perform during the pandemic; in contrast, $57.59 \%$ did not consider any procedures safe. Emergency procedures were considered safe to perform during the pandemic period by $32.99 \%$ (Table 1).

Complete social isolation, as recommended by the relevant local government, was practiced by $96.21 \%$ of the participants, although nearly $33 \%$ had a family member working outside the home. Approximately $25 \%$ of the respondents know someone who 
had contracted COVID-19. A complete report of the descriptive data is presented in Table 1.

Participants correctly identified an average of $4.29 \pm 1.52$ main symptoms of COVID-19. The most commonly identified symptoms were shortness of breath (identified by $91.34 \%$ of respondents), dry cough (90.26\%), high fever (79.81\%), sore throat $(59.48 \%)$, and headache (46.14\%) (Table 1). Knowledge of COVID-19 symptoms was influenced by factors including dental specialty, age, gender, duration since graduation, and region. Dentists who did not believe COVID-19 could be transmitted by dental procedures were less familiar with the symptoms of COVID-19 ( $p<0.001)$. Public health specialists had greater knowledge of COVID-19 symptoms $(p<0.001)$ (Table 2).

The relationships among several categorical variables were evaluated (Table 3). Dentists who were more likely to perform emergency and elective procedures shared some characteristics, such as disagreement that COVID-19 can be transmitted through dental procedures $(p<0.05)$ and confidence in the adequacy of conventional PPE and workplace biosecurity measures to prevent COVID-19 transmission ( $p<0.001$ ). Different dental specialties also demonstrated different likelihoods of performing elective and emergency dental procedures. Emergency dental care was most prevalent among public health specialists (71.90\%), whereas only $48.80 \%$ of restorative dentistry specialists performed emergency procedures $(p<0.001)$. Implant specialists had the highest prevalence of continuing to perform elective dental procedures (12.85\%), whereas only $3.11 \%$ of public health specialists provided elective treatment $(p<0.001)$. Table 3 shows other possible associations. It is noteworthy that the workplace is affected by specialty $(p<0.001)$, with public health specialists being more likely than other specialties to work in primary or secondary health-care settings (for example, $81.63 \%$ of public health specialists worked in primary or secondary health-care settings, as opposed to only $12.47 \%$ of implant specialists).

Comparisons between the various regions revealed significant influences on respondents' answers $(p<0.001)$, as shown in Table 4. Overall, endodontic treatment (95.40\%), esthetic restoration procedures (96.21\%), and dental surgeries (96.40\%) were strongly considered low priorities during the pandemic social isolation period.

A higher rate of respondents in the Northeast region believed COVID-19 could be transmitted by dental treatment; the rate was lower in the Midwest region $(p<0.001)$. Unlike in other regions, $79.80 \%$ of the respondents in the Northeast region agreed that conventional PPE was insufficient against COVID-19 transmission, and $79.10 \%$ considered their workplace's biosecurity measures insufficient $(p<0.001)$. The highest percentage of dentists continuing to perform elective dental procedures during the COVID-19 social isolation period was observed in the North region $(p<0.001)$. In the Northeast region, only $45.20 \%$ of dentists reported providing emergency dental care $(p<0.001)$. Table 4 shows the results for the descriptive analysis of each region. Figure 1 presents a summary of the study's findings for each region.

\section{Discussion}

Brazil is divided into five large geographic regions (i.e., South, Southeast, North, Northeast, and Midwest). In the present research, the greatest number of participants belonged to the Southeastern region. This may be explained once that the majority of dentists are registered in the Southeastern region, according to the Brazilian Federal Council of Dentistry. ${ }^{8}$ Moreover, all regions
Table 2: Number of COVID-19 symptoms correctly identified and its relationships with personal and practice-specific questions

\begin{tabular}{|c|c|c|c|}
\hline Variables & $\begin{array}{l}\text { COVID-19 symptoms } \\
\text { knowledge }\end{array}$ & $S D$ & $p$ value \\
\hline \multicolumn{4}{|l|}{ Field of specialty } \\
\hline General dentistry & 4.32 & 1.53 & $0.0412^{*}$ \\
\hline Oral and maxillofacial surgery & 4.28 & 1.44 & \\
\hline Restorative dentistry & 4.22 & 1.55 & \\
\hline Orofacial pain/TMD & 4.45 & 1.56 & \\
\hline Endodontics & 4.27 & 1.51 & \\
\hline Stomatology & 4.47 & 1.55 & \\
\hline Implant dentistry & 4.18 & 1.58 & \\
\hline Labor dentistry & 4.44 & 1.39 & \\
\hline Legal dentistry & 4.38 & 1.41 & \\
\hline Special needs patients & 4.24 & 1.56 & \\
\hline Periodontology & 4.25 & 1.48 & \\
\hline Dental prosthesis & 4.25 & 1.51 & \\
\hline Public health & 4.40 & 1.49 & \\
\hline Others & 4.32 & 1.52 & \\
\hline \multicolumn{4}{|l|}{ Age } \\
\hline $21-30$ years old & 4.15 & 1.42 & $<0.001^{*}$ \\
\hline $31-40$ year old & 4.25 & 1.51 & \\
\hline $41-50$ years old & 4.33 & 1.54 & \\
\hline $51-60$ years old & 4.37 & 1.58 & \\
\hline $61-70$ years old & 4.45 & 1.60 & \\
\hline$>70$ years old & 3.82 & 1.99 & \\
\hline \multicolumn{4}{|l|}{ Gender } \\
\hline Male & 4.18 & 1.55 & $<0.001^{*}$ \\
\hline Female & 4.34 & 1.52 & \\
\hline Male transgender & 4.00 & 1.73 & \\
\hline Female transgender & 4.00 & 3.00 & \\
\hline \multicolumn{4}{|l|}{ Duration since graduation } \\
\hline $0-5$ years & 4.14 & 1.48 & $<0.001^{*}$ \\
\hline $6-10$ years & 4.26 & 1.47 & \\
\hline $11-15$ years & 4.26 & 1.49 & \\
\hline $16-20$ years & 4.32 & 1.53 & \\
\hline $21-30$ years & 4.34 & 1.55 & \\
\hline$>30$ years & 4.38 & 1.59 & \\
\hline \multicolumn{4}{|l|}{ Country region } \\
\hline North & 4.20 & 1.48 & $<0.001^{*}$ \\
\hline Northeast & 4.29 & 1.45 & \\
\hline Southeast & 4.31 & 1.56 & \\
\hline South & 4.38 & 1.52 & \\
\hline Midwest & 4.08 & 1.49 & \\
\hline \multicolumn{4}{|c|}{$\begin{array}{l}\text { Can COVID- } 19 \text { be transmitted } \\
\text { through dental treatment? }\end{array}$} \\
\hline Yes & 4.31 & 1.52 & $<0.001^{*}$ \\
\hline No & 3.53 & 1.99 & \\
\hline I still have doubts & 3.48 & 1.72 & \\
\hline $\begin{array}{l}\text { Do you think conventional } \\
\text { PPE (gloves, hat, apron, } \\
\text { mask, and goggles) is suffi- } \\
\text { cient to prevent COVID-19 } \\
\text { transmission? }\end{array}$ & & & \\
\hline
\end{tabular}

Contd... 
Contd...

\begin{tabular}{llll}
\hline Variables & $\begin{array}{l}\text { COVID-19 } \\
\text { symptoms }\end{array}$ & & \\
knowledge & SD & p value \\
\hline Yes & 4.10 & 1.59 & $<0.001^{*}$ \\
No & 4.35 & 1.52 & \\
Maybe & 4.14 & 1.50 &
\end{tabular}

Do you consider the biosafety measures implemented in your work sufficient to prevent COVID-19 transmission?

Yes

4.18

No

I don't know

4.34

$1.55<0.001^{*}$

Are you performing elective dental procedures at your workplace during the pandemic period?

Yes

No

Are you performing emergency dental procedures at your workplace during the pandemic period?

Yes

No

Are you and your family members qua antined or practicing social isolation?

Yes

No

Yes, but some of my family members are still working

Where do you provide dental treatment?

Private practice (own office)

Yes

No

Private practice (franchised/popular clinic)

Yes

No

Private practice (private hospital)

Yes

No

Public health (primary/secondary health care)

Yes

No

Public health (tertiary health care/ public hospital)

Yes

No

Private university/faculty

Yes

No

Public university/faculty

\begin{tabular}{llll} 
Yes & 4.28 & 1.42 & 0.9166 \\
No & 4.29 & 1.53 & \\
\hline
\end{tabular}

of Brazil were significantly represented, avoiding a possible sample bias.

Respondents identified shortness of breath (91.34\%), dry cough $(90.26 \%)$, high fever $(79.81 \%)$, sore throat $(59.48 \%)$, and headache $(46.14 \%)$ as main symptoms of COVID-19. The Centers for Disease Control and Prevention identifies shortness of breath, dry cough, and high fever as the principle symptoms; the WHO identifies fever, fatigue, and dry cough. Some patients may present muscle aches, runny nose, nasal congestion, diarrhea, or sore throat. ${ }^{11}$ The symptoms are usually mild and benign gradually. Some individuals may become infected without developing any symptoms or feeling unwell. ${ }^{12}$ Recently, Xu et al. ${ }^{13}$ reported that salivary glands may be potential reservoirs for COVID-19 asymptomatic infection.

The immense majority of participants (98.07\%) agreed that COVID-19 can be transmitted by saliva, rendering dental procedures hazardous for disease propagation; this is consistent with current scientific evidence. ${ }^{2,9,12,14}$ Because dental procedures pose a high risk of transmission, elective treatments should be postponed until the pandemic is stabilized., ${ }^{9,10}$ The American Dental Association (ADA) has summarized urgent and emergent situations to provide dental professionals with guidance on how to minimize the risks of COVID-19 transmission when performing dental procedures. ${ }^{10}$ The most common situations that necessitate dental treatment during the pandemic period are severe dental pain from pulpal inflammation; pericoronitis or third-molar pain; postoperative osteitis; localized pain and swelling due to abscess or bacterial infection; dental trauma resulting in pain or soft tissue laceration; dental avulsion/luxation; final crown/ bridge cementation, if the temporary restoration is lost, broken, or causing gingival irritation; replacement of temporary fillings on endo access openings for patients experiencing pain; and orthodontic wire or appliances piercing or ulcerating the oral mucosa, which must be snipped or adjusted. 9,10

Biosecurity measures are necessary to protect both patients and dental professionals during dental treatment. Therefore, use of PPE (gown, mask, goggles or face shield, and gloves) and safe work practices to protect dental equipment and limit contamination are particularly crucial, such as keeping the hands away from the face, limiting surfaces touched, changing torn or contaminated gloves, and proper handwashing before and after dental care, according to Ather et al. ${ }^{9}$ In this study, 11,691 participants (73.93\%) had doubt in the ability of conventional PPE to prevent COVID-19 transmission, and only $18.06 \%$ of the respondents considered their workplace's current biosecurity measures sufficient to prevent possible infection. Biosecurity recommendations for dental procedures have been consistently disseminated by previous studies and should already be employed by dentists and assistants as a routine practice. ${ }^{9,12}$ Additional care during removal of PPE is also recommended during the pandemic period to avoid contact with clothing, skin, or mucous membranes, due to the high transmission potential of contaminated materials., ${ }^{9,12}$

Dental professionals are at high risk of nosocomial infection and can be potential carriers of COVID-19. ${ }^{2,9,15}$ These facts are consistent with the responses of most study participants, particularly those in the Northeast region, who acknowledged that COVID-19 could be transmitted through dental treatment (Table 4). However, some respondents in the Midwest region did not believe COVID-19 could be transmitted through dental treatment (Tables 3 and 4). These findings are concerning because dental treatments produce a large 

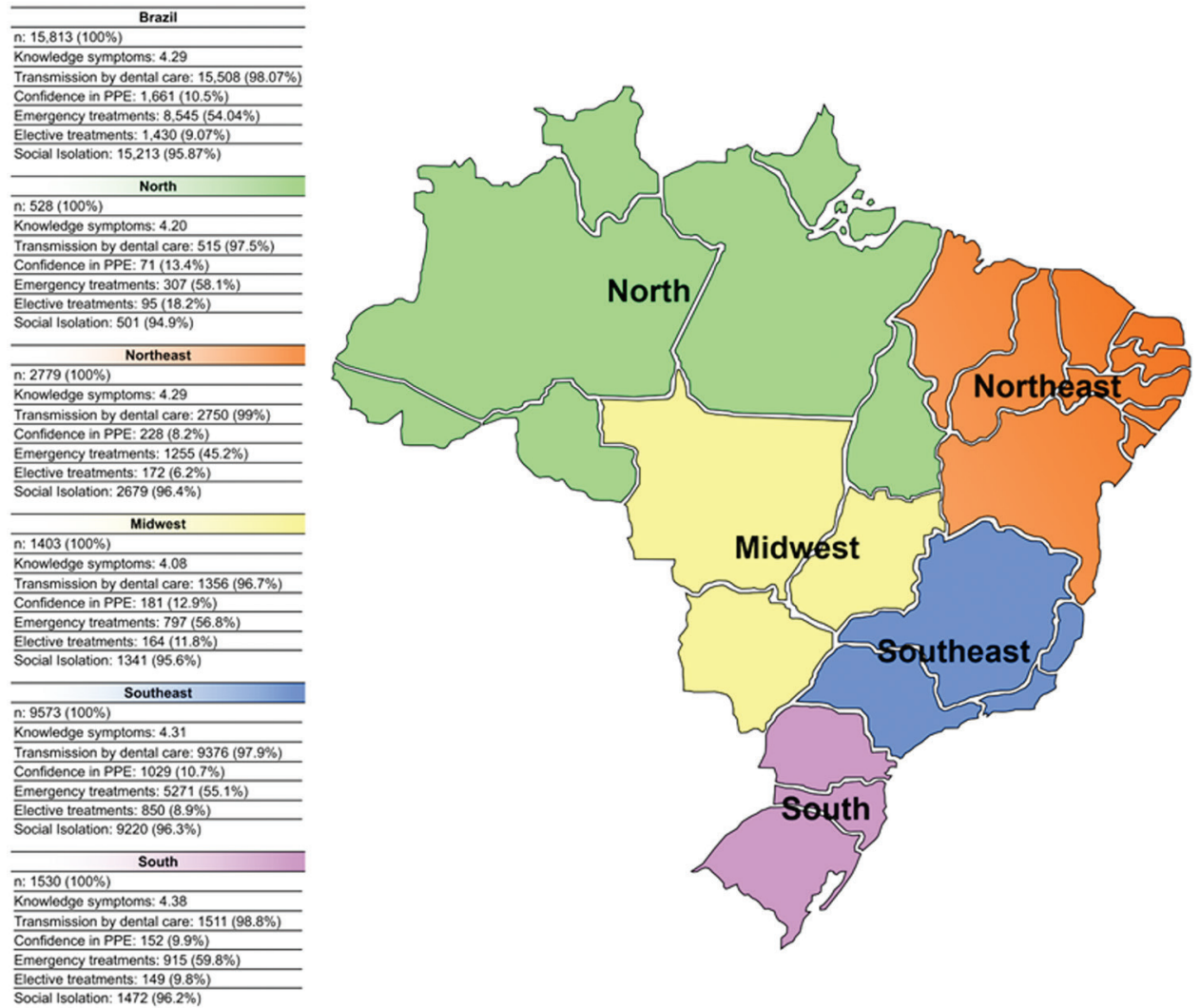

Fig. 1: Responses to the questionnaire according to each region of Brazil

number of droplets and aerosols, the principle transmission routes for COVID-19 infection. ${ }^{12,16}$ Additionally, if dental patients cough or sneeze, their secretions, saliva, or blood aerosolize and can infect individuals in close proximity (within approximately $2 \mathrm{~m}$ ). ${ }^{9,12,13}$

Recent findings suggest that saliva is an important mode of transmission of COVID-19. ${ }^{2,13}$ Once that COVID-19 may be present in asymptomatic patients, dentists should observe standard, contact, and airborne biosecurity precautions, including appropriate use of PPE (disposable medical caps, disposable surgical masks, goggles, face masks, and a work coat with external insulation or surgical clothes, and disposable latex gloves) and hand hygiene practices. ${ }^{2,12,16}$ The use of half-mask filtering facepiece respirators, as $\mathrm{N} 95$ respirators, is essential to prevent aerosol and droplet transmission, presenting better protection than surgical masks. ${ }^{17}$ Another recommendation is to perform a preprocedural mouth rinse with $0.2 \%$ povidone-iodine $e^{9,12,18}$ or $0.5-1.0 \%$ hydrogen peroxide $^{19}$ to reduce the viral load in saliva. Ather et al. ${ }^{9}$ observed that the use of disposable devices, such as powerful suction pumps, is encouraged to avoid cross-contamination, as is the use of a rubber dam to minimize splatter. Clinic staff should take care to disinfect surfaces using chemicals recently approved for COVID-19 and to maintain a dry environment. ${ }^{20}$ Respondents in this study who considered their workplace's biosecurity measures and PPE sufficient to prevent COVID-19 transmission were more likely to perform both elective and emergency dental procedures (Table 3). However, a limitation of this study's results is that the actual biosecurity measures employed by these dentists were not investigated. So, the observation with biosecurity during dental procedures should be adopted in all appointments, with all patients.
The latest update (March 16, 2020) from the ADA recommends American dentists defer elective dental treatment for the next 3 weeks, focusing only on emergency care. ${ }^{10}$ Similarly, the Brazilian public health system recommends prioritizing cases of pain, infection, and suffering. ${ }^{21,22}$ However, dentists' likelihood of providing emergency care differs according to their field of specialty. In the present study, $71.9 \%$ of public health specialists performed emergency dental care and thus face greater exposure to potential COVID-19 infection (Table 3). It should be noted that these professionals are commonly linked to primary and secondary public health-care services, which have continued their activities during the COVID-19 pandemic and provide urgent dental care, as recommended by public health authorities.

This study observed that the majority of dentists in the North region continued to perform elective dental procedures. Thus, these professionals are also at greater risk of contracting and spreading COVID-19 (Table 4). Lower awareness of and adherence to disease control strategies are associated with a greater risk of susceptibility to infectious diseases, such as COVID-19. Therefore, to mitigate the effects of the disease, public health policies should target groups at higher risk of contracting and transmitting COVID-19.

Prevention of infection in dental offices is difficult if dentists are not concerned with adherence to the biosecurity protocol. The appearance of a clean office does not necessarily indicate that surfaces and equipment are properly disinfected and sterilized. An effective dental office, whether public or private, should incorporate biosecurity measures into its permanent routines, according to Garbin et al. ${ }^{23}$ In Brazil, private offices are frequently seen as models of infection control. ${ }^{23}$ This is 
Table 3: Relationships between categorical variables

\begin{tabular}{|c|c|c|c|}
\hline Variable 1 & Variable 2 & $p$-value & Interpretation \\
\hline $\begin{array}{l}\text { Belief that COVID-19 can be } \\
\text { transmitted through dental } \\
\text { treatment }\end{array}$ & $\begin{array}{l}\text { Performing emergency } \\
\text { procedures }\end{array}$ & 0.047 & $\begin{array}{l}\text { Dentists who don't believe COVID-19 can be transmitted through } \\
\text { dental treatment are more likely to perform emergency dental } \\
\text { procedures. }\end{array}$ \\
\hline $\begin{array}{l}\text { Belief that COVID-19 can be } \\
\text { transmitted through dental } \\
\text { treatment }\end{array}$ & $\begin{array}{l}\text { Performing elective } \\
\text { procedures }\end{array}$ & $<0.001$ & $\begin{array}{l}\text { Dentists who don't believe COVID-19 can be transmitted through } \\
\text { dental treatment are more likely to perform elective dental } \\
\text { procedures. }\end{array}$ \\
\hline $\begin{array}{l}\text { Belief that conventional PPE is } \\
\text { sufficient to prevent COVID-19 } \\
\text { transmission }\end{array}$ & $\begin{array}{l}\text { Performing emergency } \\
\text { procedures }\end{array}$ & $<0.001$ & $\begin{array}{l}\text { Dentists who believe conventional PPE is sufficient to prevent } \\
\text { COVID-19 transmission are more likely to perform emergency } \\
\text { dental procedures. }\end{array}$ \\
\hline $\begin{array}{l}\text { Belief that conventional PPE is } \\
\text { sufficient to prevent COVID-19 } \\
\text { transmission }\end{array}$ & $\begin{array}{l}\text { Performing elective } \\
\text { procedures }\end{array}$ & $<0.001$ & $\begin{array}{l}\text { Dentists who believe conventional PPE is sufficient to prevent } \\
\text { COVID-19 transmission are more likely to perform elective dental } \\
\text { procedures. }\end{array}$ \\
\hline $\begin{array}{l}\text { Belief that workplace biosecurity } \\
\text { measures are sufficient to } \\
\text { prevent COVID-19 transmission }\end{array}$ & $\begin{array}{l}\text { Performing emergency } \\
\text { procedures }\end{array}$ & $<0.001$ & $\begin{array}{l}\text { Dentists who believe that their workplace's biosecurity measures } \\
\text { are sufficient to prevent COVID- } 19 \text { transmission are more likely to } \\
\text { perform emergency dental procedures. }\end{array}$ \\
\hline $\begin{array}{l}\text { Belief that workplace biosecurity } \\
\text { measures are sufficient to } \\
\text { prevent COVID-19 transmission }\end{array}$ & $\begin{array}{l}\text { Performing elective } \\
\text { procedures }\end{array}$ & $<0.001$ & $\begin{array}{l}\text { Dentists who believe that their workplace's biosecurity measures } \\
\text { are sufficient to prevent COVID- } 19 \text { transmission are more likely to } \\
\text { perform elective dental procedures. }\end{array}$ \\
\hline Dental specialty & $\begin{array}{l}\text { Performing emergency } \\
\text { procedures }\end{array}$ & $<0.001$ & $\begin{array}{l}\text { Some dental specialties are more likely to perform emergency } \\
\text { dental procedures ( } 71.9 \% \text { of public health specialists vs } 48.8 \% \text { of } \\
\text { restorative dentistry specialists). }\end{array}$ \\
\hline Dental specialty & $\begin{array}{l}\text { Performing elective } \\
\text { procedures }\end{array}$ & $<0.001$ & $\begin{array}{l}\text { Some dental specialties are more likely to perform elective dental } \\
\text { procedures ( } 12.85 \% \text { of implant specialists vs } 3.11 \% \text { of public health } \\
\text { specialists). }\end{array}$ \\
\hline Region & $\begin{array}{l}\text { Performing emergency } \\
\text { procedures }\end{array}$ & $<0.001$ & $\begin{array}{l}\text { Dentists from some regions are more likely to perform emergency } \\
\text { dental procedures ( } 59.80 \% \text { of dentists from the South region vs } \\
45.16 \% \text { from the Northeast region). }\end{array}$ \\
\hline Region & $\begin{array}{l}\text { Performing elective } \\
\text { procedures }\end{array}$ & $<0.001$ & $\begin{array}{l}\text { Dentists from some regions are more likely to perform elective } \\
\text { dental procedures ( } 18.16 \% \text { of dentists from the North region vs } \\
6.20 \% \text { from the Northeast region). }\end{array}$ \\
\hline $\begin{array}{l}\text { Belief that workplace biosecurity } \\
\text { measures are sufficient to } \\
\text { prevent COVID-19 transmission }\end{array}$ & Private practice & $<0.001$ & $\begin{array}{l}\text { Dentists who work in private practice are more likely to consider } \\
\text { their workplace's biosecurity measures sufficient to prevent } \\
\text { COVID-19 transmission. }\end{array}$ \\
\hline $\begin{array}{l}\text { Belief that workplace biosecurity } \\
\text { measures are sufficient to } \\
\text { prevent COVID-19 transmission }\end{array}$ & $\begin{array}{l}\text { Private practice } \\
\text { (franchised/popular } \\
\text { dental clinic) }\end{array}$ & $<0.001$ & $\begin{array}{l}\text { Dentists who work in private franchised/popular dental clinics } \\
\text { are more likely to consider their workplace's biosecurity measures } \\
\text { insufficient to prevent COVID-19 transmission. }\end{array}$ \\
\hline $\begin{array}{l}\text { Belief that workplace biosecurity } \\
\text { measures are sufficient to } \\
\text { prevent COVID-19 transmission }\end{array}$ & $\begin{array}{l}\text { Private practice } \\
\text { (hospital) }\end{array}$ & 0.118 & No relationship between these variables. \\
\hline $\begin{array}{l}\text { Belief that workplace biosecurity } \\
\text { measures are sufficient to } \\
\text { prevent COVID-19 transmission }\end{array}$ & $\begin{array}{l}\text { Public health (primary/ } \\
\text { secondary health care) }\end{array}$ & $<0.001$ & $\begin{array}{l}\text { Dentists who work in public primary/secondary health care are less } \\
\text { likely to consider their workplace's biosecurity measures sufficient } \\
\text { to prevent COVID-19 transmission. }\end{array}$ \\
\hline $\begin{array}{l}\text { Belief that workplace biosecurity } \\
\text { measures are sufficient to } \\
\text { prevent COVID-19 transmission }\end{array}$ & $\begin{array}{l}\text { Public health (public } \\
\text { hospitals) }\end{array}$ & 0.002 & $\begin{array}{l}\text { Dentists who are unsure whether their workplace's biosecurity } \\
\text { measures are sufficient to prevent COVID-19 transmission tend to } \\
\text { be less involved in public hospital practice. }\end{array}$ \\
\hline $\begin{array}{l}\text { Belief that workplace biosecurity } \\
\text { measures are sufficient to } \\
\text { prevent COVID-19 transmission }\end{array}$ & $\begin{array}{l}\text { Practice in private } \\
\text { universities/faculties }\end{array}$ & 0.936 & No relationship between these variables. \\
\hline $\begin{array}{l}\text { Belief that workplace biosecurity } \\
\text { measures are sufficient to } \\
\text { prevent COVID-19 transmission }\end{array}$ & $\begin{array}{l}\text { Practice in public } \\
\text { universities/faculties }\end{array}$ & 0.027 & $\begin{array}{l}\text { Dentists who work in public universities are more likely to consider } \\
\text { their workplace's biosecurity measures sufficient to prevent } \\
\text { COVID-19 transmission. }\end{array}$ \\
\hline $\begin{array}{l}\text { Belief that conventional PPE is } \\
\text { sufficient to prevent COVID-19 } \\
\text { transmission }\end{array}$ & Private practice & $<0.001$ & $\begin{array}{l}\text { Dentists who work in private practice are more likely to consider } \\
\text { conventional PPE sufficient to prevent COVID-19 transmission. }\end{array}$ \\
\hline $\begin{array}{l}\text { Belief that conventional PPE is } \\
\text { sufficient to prevent COVID-19 } \\
\text { transmission }\end{array}$ & $\begin{array}{l}\text { Private practice } \\
\text { (franchised/popular } \\
\text { clinic) }\end{array}$ & $<0.001$ & $\begin{array}{l}\text { Dentists who work in private franchised/popular dental clinics are } \\
\text { more likely to consider conventional PPE insufficient to prevent } \\
\text { COVID-19 transmission. }\end{array}$ \\
\hline
\end{tabular}


Contd...

\begin{tabular}{|c|c|c|c|}
\hline Variable 1 & Variable 2 & $p$-value & Interpretation \\
\hline $\begin{array}{l}\text { Belief that conventional PPE is } \\
\text { sufficient to prevent COVID-19 } \\
\text { transmission }\end{array}$ & $\begin{array}{l}\text { Private practice } \\
\text { (hospitals) }\end{array}$ & 0.031 & $\begin{array}{l}\text { Dentists who work in private hospitals are less likely to consider } \\
\text { conventional PPE sufficient to prevent COVID-19 transmission. }\end{array}$ \\
\hline $\begin{array}{l}\text { Belief that conventional PPE is } \\
\text { sufficient to prevent COVID-19 } \\
\text { transmission }\end{array}$ & $\begin{array}{l}\text { Public health (primary/ } \\
\text { secondary health care) }\end{array}$ & $<0.001$ & $\begin{array}{l}\text { Dentists who work in public primary/secondary health care are less } \\
\text { likely to consider conventional PPE sufficient to prevent COVID-19 } \\
\text { transmission. }\end{array}$ \\
\hline $\begin{array}{l}\text { Belief that conventional PPE is } \\
\text { sufficient to prevent COVID-19 } \\
\text { transmission }\end{array}$ & $\begin{array}{l}\text { Public health (public } \\
\text { hospitals) }\end{array}$ & 0.012 & $\begin{array}{l}\text { Dentists who are unsure whether conventional PPE is sufficient to } \\
\text { prevent COVID- } 19 \text { transmission tend to be less involved in public } \\
\text { hospital practice. }\end{array}$ \\
\hline $\begin{array}{l}\text { Belief that conventional PPE is } \\
\text { sufficient to prevent COVID-19 } \\
\text { transmission }\end{array}$ & $\begin{array}{l}\text { Practice in private } \\
\text { universities/faculties }\end{array}$ & 0.731 & No relationship between these variables. \\
\hline $\begin{array}{l}\text { Belief that conventional PPE is } \\
\text { sufficient to prevent COVID-19 } \\
\text { transmission }\end{array}$ & $\begin{array}{l}\text { Practice in public } \\
\text { universities/faculties }\end{array}$ & 0.301 & No relationship between these variables. \\
\hline
\end{tabular}

consistent with the responses received in this study, showing that dentists working in private practice were more likely to consider their workplace's biosecurity measures and PPE sufficient to prevent COVID-19 transmission (Table 3). However, some studies have revealed flaws in biosecurity protocol even in private clinics, ${ }^{23-25}$ with negligent use of PPE being one of the most frequent. ${ }^{23,24}$ Professionals have reported that biosafety protocols are difficult to follow, one factor that relates to noncompliance with biosecurity measures.

In contrast, an association between lower financial resources and investment in an office and worse infection control conditions has also been observed. ${ }^{23}$ In humble areas, limited dental offices had conditions adequate to ensure cross-infection control. The worst conditions were found in public dental services and private clinics in peripheral regions. This is consistent with the present study's results, in which respondents working in primary or secondary public health services and popular or franchised private dental clinics were less likely to consider PPE and biosecurity measures sufficient to prevent COVID-19 transmission (Table 3). Similarly, Garbin et al. ${ }^{23}$ observed more flaws in public offices than private offices in the use of protective barriers: Caps were used by $55 \%$ of public sector professionals versus $90 \%$ of private-sector professionals; proper glove changing was observed in $100 \%$ of private-sector professionals versus $60 \%$ of public-sector professionals; and only $25 \%$ of public dental offices supplied protective glasses for patients versus $65 \%$ of private offices. According to the present study's results, mistrust of biosafety measures also extends to dentists working in public hospitals (Table 3).

Brazil is a country with continental dimensions and immense economic and social inequality between regions. The regions of the central south axis (Midwest, Southeast, and South) are more economically privileged than the North and Northeast regions. ${ }^{6}$ Implementation of infection control barriers can be influenced, among other things, by economic issues.$^{26}$ In the Northeast region, $79.80 \%$ of the respondents reported that PPE was insufficient to prevent COVID-19 transmission, and $79.10 \%$ considered their workplace's biosecurity measures insufficient (Table 4). Economic issues may have influenced the implementation of biosecurity barriers in health facilities in the Northeast region, as reflected in these participants' responses.

\section{Conclusion}

It is possible to conclude that, during the COVID-19 pandemic, Brazilian dentists demonstrated high knowledge of the risks of transmission through dental procedures and the basic symptoms of COVID-19. Social isolation was practiced by the majority of respondents, although some professionals continued to provide emergency dental care.

\section{Author Contributions}

George Táccio de Miranda Candeiro contributed to the conception, design, data acquisition, and analysis, drafted and critically revised the manuscript; Jiovanne Rabelo Neri contributed to the conception, design, and data acquisition, drafted and critically revised the manuscript; Bruna Marjorie Dias Frota de Carvalho contributed to the conception, design, analysis, and interpretation and critically revised the manuscript. Camila Pontes Feijão contributed to the conception, design, analysis, and interpretation and critically revised the manuscript; Rafael Linard Avelar contributed to the analysis and interpretation and critically revised the manuscript; José Vítor Mota Lemos contributed to statistical analysis, interpretation, and drawing and critically revised the manuscript; Anya Pimentel Gomes Fernandes Vieira Meyer contributed to data acquisition, statistical analysis, and interpretation and drafted and critically revised the manuscript; All authors gave final approval and agree to be accountable for all aspects of the work.

\section{Compliance with Ethical Standards}

Ethical approval: The present research was approved by the Ethics Committee of University Center Christus, Fortaleza, Brazil (Protocol number: 30535020.5.0000.5049). All procedures performed in studies involving human participants were in accordance with the ethical standards of the institutional and/or national research committee and with the 1964 Helsinki declaration and its later amendments or comparable ethical standards.

Informed consent: Informed consent was obtained from all individual participants and included in the study. 
Table 4: Distribution of answers by number and percent according to geographic region

\begin{tabular}{|c|c|c|c|c|c|c|}
\hline Specific questions and answers & North & Northeast & Southeast & South & Midwest & $p$ value \\
\hline \multicolumn{7}{|l|}{$\begin{array}{l}\text { Can COVID-19 be transmitted through dental } \\
\text { treatment? }\end{array}$} \\
\hline Yes & $515(97.5)$ & $2750(99)$ & $9376(97.9)$ & $1511(98.8)$ & $1356(96.7)$ & $<0.001$ \\
\hline No & $7(1.3)$ & $9(0.3)$ & $62(0.6)$ & $1(0.1)$ & $13(0.9)$ & \\
\hline I still have doubts & $6(1.1)$ & $20(0.7)$ & $135(1.4)$ & $18(1.2)$ & $34(2.4)$ & \\
\hline Total & $528(100)$ & $2779(100)$ & $9573(100)$ & $1530(100)$ & $1403(100)$ & \\
\hline \multicolumn{7}{|l|}{$\begin{array}{l}\text { Do you think conventional PPE (gloves, hat, apron, } \\
\text { mask, and goggles) is sufficient to prevent COVID-19 } \\
\text { transmission? }\end{array}$} \\
\hline Yes & $71(13.4)$ & $228(8.2)$ & $1029(10.7)$ & $152(9.9)$ & $181(12.9)$ & $<0.001$ \\
\hline No & $388(73.5)$ & $2217(79.8)$ & $6959(72.7)$ & $1129(73.8)$ & $998(71.1)$ & \\
\hline Maybe & $69(13.1)$ & $334(12)$ & $1585(16.6)$ & $249(16.3)$ & $224(16)$ & \\
\hline Total & $528(100)$ & $2779(100)$ & $9573(100)$ & $1530(100)$ & $1403(100)$ & \\
\hline \multicolumn{7}{|c|}{$\begin{array}{l}\text { Do you consider the biosafety measures implemented in } \\
\text { your work sufficient to prevent COVID-19 transmission? }\end{array}$} \\
\hline Yes & $102(19.3)$ & $345(12.4)$ & $1839(19.2)$ & $288(18.8)$ & $282(20.1)$ & $<0.001$ \\
\hline No & $348(65.9)$ & $2198(79.1)$ & $6327(66.1)$ & $1013(66.2)$ & $931(66.4)$ & \\
\hline Idon't know & $78(14.8)$ & $236(8.5)$ & $1407(14.7)$ & $229(15)$ & $190(13.5)$ & \\
\hline Total & $528(100)$ & $2779(100)$ & $9573(100)$ & $1530(100)$ & $1403(100)$ & \\
\hline \multicolumn{7}{|l|}{$\begin{array}{l}\text { What procedures do you consider safe to perform } \\
\text { during the COVID-19 pandemic? }\end{array}$} \\
\hline None & $273(51.7)$ & $1726(62.1)$ & $5508(57.5)$ & $849(55.5)$ & $751(53.5)$ & $<0.001$ \\
\hline Restorative and aesthetic procedures & $20(3.8)$ & $83(3)$ & $360(3.8)$ & $78(5.1)$ & $59(4.2)$ & 0.012 \\
\hline Surgical procedures & $19(3.6)$ & $99(3.6)$ & $349(3.6)$ & $56(3.7)$ & $46(3.3)$ & 0.973 \\
\hline Endodontic treatments & $26(4.9)$ & $79(2.8)$ & $458(4.8)$ & $84(5.5)$ & $81(5.8$ & $<0.001$ \\
\hline Urgent/emergency treatments & $192(36.4)$ & $870(31.3)$ & $3160(33)$ & $526(34.4)$ & $469(33.4)$ & 0.102 \\
\hline All procedures & $52(9.8)$ & $157(5.6)$ & $818(8.5)$ & $146(9.5)$ & $165(11.8)$ & $<0.001$ \\
\hline \multicolumn{7}{|l|}{$\begin{array}{l}\text { Are you performing elective dental procedures at your } \\
\text { workplace during the pandemic period?*}\end{array}$} \\
\hline Yes & $95(18.2)$ & $172(6.2)$ & $850(8.9)$ & $149(9.8)$ & $164(11.8)$ & $<0.001$ \\
\hline No & $428(81.8)$ & $2604(93.8)$ & $8695(91.1)$ & $1379(90.2)$ & $1230(88.2)$ & \\
\hline Total & $523(100)$ & $2776(100)$ & $9545(100)$ & $1528(100)$ & $1394(100)$ & \\
\hline \multicolumn{7}{|l|}{$\begin{array}{l}\text { Are you performing emergency dental procedures at } \\
\text { your workplace during the pandemic period? }\end{array}$} \\
\hline Yes & $307(58.1)$ & $1255(45.2)$ & $5271(55.1)$ & $915(59.8)$ & $797(56.8)$ & $<0.001$ \\
\hline No & $221(41.9)$ & $1524(54.8)$ & $4302(44.9)$ & $615(40.2)$ & $606(43.2)$ & \\
\hline Total & $528(100)$ & $2779(100)$ & $9573(100)$ & $1530(100)$ & $1403(100)$ & \\
\hline \multicolumn{7}{|l|}{$\begin{array}{l}\text { Are you and your family members quarantined or } \\
\text { practicing social isolation? }\end{array}$} \\
\hline Yes & $282(53.4)$ & $1612(58)$ & $6296(65.8)$ & 1019 (66.6) & $788(56.2)$ & $<0.001$ \\
\hline No & $27(5.1)$ & $100(3.6)$ & $353(3.7)$ & $58(3.8)$ & $62(4.4)$ & \\
\hline Yes, but 1 or more family members are still working & $219(41.5)$ & $1067(38.4)$ & $2924(30.5)$ & $453(29.6)$ & $553(39.4)$ & \\
\hline Total & $(100)$ & $2779(100)$ & $9573(100)$ & $1530(100)$ & $1403(100)$ & \\
\hline
\end{tabular}

*Number of answers was less

\section{ORCID}

George TM Candeiro @ https://orcid.org/0000-0003-2512-0554

Jiovanne R Neri $\odot$ https://orcid.org/0000-0001-6447-0384

Bruna MDF de Carvalho (1) https://orcid.org/0000-0002-6468-0477

Camila P Feijão 누 https://orcid.org/0000-0002-3815-2638

Rafael L Avelar (1) https://orcid.org/0000-0003-2984-3063

José VM Lemos (1) https://orcid.org/0000-0001-9020-1532

Anya PGF Vieira-Meyer $\odot$ https://orcid.org/0000-0003-4237-8995

\section{References}

1. An $\mathrm{P}$, Song $\mathrm{P}$, Lian $\mathrm{K}$, et al. CT manifestations of novel coronavirus pneumonia: a case report. Balkan Med J 2020;37(3):163-165. DOI: 10.4274/balkanmedj.galenos.2020.2020.2.15.

2. Peng X, Xu X, Li Y, et al. Transmission routes of 2019-nCoV and controls in dental practice. Int J Oral Sci 2020;12(1):9. DOI: 10.1038/ s41368-020-0075-9.

3. Sohrabi C, Alsafi Z, O'Neill N, et al. World Health Organization declares global emergency: a review of the 2019 novel coronavirus (COVID-19). Int J Surg 2020;76:71-76. DOI: 10.1016/j.ijsu.2020.02.034. 
4. World Health Organization. Consideration for quarantine of individuals in the context of containment for coronavirus disease (COVID-19); 2020. Available from: https://www.who.int/ publications-detail/considerations-for-quarantine-of-individualsin-the-context-of-containment-for-coronavirus-disease(covid-19).

5. World Health Organization. Coronavirus disease (COVID-19) Situation dashboard; 2020. Available from: https://covid19.who.int.

6. Ministério da Saúde do Brasil. Painel coronavírus. Available from: https://COVID.saude.gov.br/.

7. Instituto Brasileiro de Geografia e Estatística. IBGE divulga o rendimento domiciliar per capita 2018. Available from: ftp:// ftp.ibge.gov.br/Trabalho_e_Rendimento/Pesquisa_Nacional_por_ Amostra_de_Domicilios_continua/Renda_domiciliar_per_capita/ Renda_domiciliar_per_capita_2018.pdf.

8. Conselho Federal de Odontologia; 2020. Available from: http:// website.cfo.org.br/profissionais-cadastrados/?cro=Todos\&categori $a=1$ \&especialidade $=$ todas\&inscricao $=$ \&nome $=$.

9. Ather A, Patel B, Ruparel NB, et al. Coronavirus disease 19 (COVID-19): implications for clinical dental care. J Endod 2020;46(5):584-595. DOI: 10.1016/j.joen.2020.03.008.

10. American Dental Association. ADA recommending dentists postpone elective procedures; 2020. Available from: https://www.ada.org/en/ publications/ada-news/2020-archive/march/ada-recommendingdentists-postpone-elective-procedures.

11. World Health Organization. Coronavirus; 2020. Available from: https://www.who.int/health-topics/coronavirus\#tab=tab_3.

12. Meng L, Hua F, Bian Z. Coronavirus disease 2019 (COVID-19): emerging and future challenges for dental and oral medicine. J Dent Res 2020;99(5):481-487. DOI: 10.1177/0022034520914246.

13. $\mathrm{Xu} \mathrm{J,} \mathrm{Li} \mathrm{Y,} \mathrm{Gan} \mathrm{F,} \mathrm{et} \mathrm{al.} \mathrm{Salivary} \mathrm{glands:} \mathrm{potential} \mathrm{reservoirs} \mathrm{for}$ COVID-19 asymptomatic infection. J Dent Res 2020;22034520918518. DOI: $10.1177 / 0022034520918518$.

14. Xu R, Cui B, Duan X, et al. Saliva: potential diagnostic value and transmission of 2019-nCoV. Int J Oral Sci 2020;12(1):11. DOI: 10.1038/ s41368-020-0080-z.
15. Sabino-Silva R, Jardim ACG, Siqueira WL. Coronavirus COVID-19 impacts to dentistry and potential salivary diagnosis. Clin Oral Investig 2020;24(4):1619-1621. DOI: 10.1007/s00784-020-03248-x.

16. Centers for Disease Control and Prevention. Transmission of coronavirus disease 2019 (COVID-19); 2020. Available from: https://www.cdc.gov/coronavirus/2019-ncov/about/transmission.html.

17. Umer F, Haji Z, Zafar K. Role of respirators in controlling the spread of novel coronavirus (Covid-19) among dental health care providers: a review. Int Endod J 2020. DOI: 10.1111/iej.13313.

18. Kariwa H, Fujii N, Takashima I. Inactivation of SARS coronavirus by means of povidone-iodine, physical conditions, and chemical reagents. Jpn J Vet Res 2004;52(3):105-112. DOI: 10.1159/000089211

19. Kampf G, Todt D, Pfaender S, et al. Persistence of coronaviruses on inanimate surfaces and its inactivation with biocidal agents. J Hosp Infect 2020;104(3):246-251. DOI: 10.1016/j.jhin.2020.01.022.

20. Hokett SD, Honey JR, Ruiz F, et al. Assessing the effectivess of direct digital radiography barrier sheaths and finger cots. J Am Dent Assoc 2000;131(4):463-467. DOI: 10.14219/jada.archive.2000.0202.

21. Antunes JL, Narvai PC. Dental health policies in Brazil and their impact on health inequalities. Rev Saude Publica 2010;44(2):360-365. DOI: 10.1590/S0034-89102010005000002.

22. Innes NP, Evans DJ. Evidence of improved access to dental care with direct access arrangements. Evid Based Dent 2013;14(2):36-37. DOI: 10.1038/sj.ebd.6400926.

23. Garbin AJ, Garbin CAS, Arcieri RM, et al. Biosecurity in public and private office. J Appl Oral Sci 2005;13(2):163-166. DOI: 10.1590/ S1678-77572005000200013.

24. Davis D, Begole EA. Compliance with infection control procedures among Illinois orthodontists. Am J Orthod Dentofacial Orthop 1998;113(6):647-654. DOI: 10.1016/s0889-5406(98)70225-2.

25. Galvani AP. Emerging infections: what have we learned from SARS? Emerg Infect Dis 2004;10(7):1351-1352. DOI: 10.3201/ eid1007.040166.

26. Gilbert M, Pullano G, Pinotti F, et al. Preparedness and vulnerability of African countries against importations of COVID-19: a modelling study. Lancet 2020;395(10227):871-877. DOI: 10.1016/S0140-6736(20)30411-6. 